\title{
A Modeling Study on the Influence of Sea-Level Rise and Channel Deepening on Estuarine Circulation and Dissolved Oxygen Levels in the Tidal James River, Virginia, USA
}

\author{
Ya Wang ${ }^{1}$ and Jian Shen ${ }^{2, *}$ \\ 1 The Third Institution of Oceanography, Ministry of Natural Resource, Xiamen 361005, China; \\ wangya@tio.org.cn \\ 2 Virginia Institute of Marine Science, William \& Mary, Gloucester Point, VA 23062, USA \\ * Correspondence: shen@vims.edu; Tel.: +804-684-7359
}

Received: 1 October 2020; Accepted: 19 November 2020; Published: 21 November 2020 updates

\begin{abstract}
The impact of channel deepening and sea-level rise on the environmental integrity of an estuary is investigated using a three-dimensional hydrodynamic-eutrophication model. The model results show that dissolved oxygen (DO) only experienced minor changes, even when the deep channel was deepened by $3 \mathrm{~m}$ in the mesohaline and polyhaline regions of the James River. We found that vertical stratification decreased $\mathrm{DO}$ aeration while the estuarine gravitational circulation increased bottom DO exchange. The interactions between these two processes play an important role in modulating DO. The minor change in DO due to channel deepening indicates that the James River is unique as compared with other estuaries. To understand the impact of the hydrodynamic changes on $\mathrm{DO}$, both vertical and horizontal transport timescales represented by water age were used to quantify the changes in hydrodynamic conditions and DO variation, in addition to traditional measures of stratification and circulation. The model results showed that channel deepening led to an increase in both gravitational circulation strength and vertical stratification. Saltwater age decreased and vertical exchange time increased with increases in channel depth. However, these two physical processes can compensate each other, resulting in minor changes in DO. A comparison of the impact of a sea-level rise of $1.0 \mathrm{~m}$ with channel deepening scenarios was conducted. As the sea level rises, the vertical transport time decreases slightly while the strength of gravitational circulation weakens due to an increase in mean water depth. Consequently, DO in the estuary experiences a moderate decrease.
\end{abstract}

Keywords: dissolved oxygen; gravitational circulation; saltwater age; vertical exchange time; channel deepening; sea-level rise; James River

\section{Introduction}

To accommodate economic development, more and more anthropogenic interventions, such as reclamation, harbor constructions, flood control measures, and channel dredging, have occurred in estuaries around the world. Because of the need for port development, channel deepening is often needed to maintain and enhance navigation. It is critical that sustainable port development preserves ecological integrity. The impact of channel deepening and its impact on the environmental integrity of an estuary are concurrent concerns.

Many studies have shown that channel deepening can affect tidal characteristics, resulting in as increase and a decrease in tidal range, estuarine stratification, and estuarine circulation [1-6]. Channel deepening often causes a decrease in dissolved oxygen (DO) [7-10]. A recent study of the Chesapeake 
Bay showed that a sea-level rise of $0.5 \mathrm{~m}$ increased bottom $\mathrm{DO}$ and reduced summer hypoxia volume by $12 \%$ [11,12]. DO is an important measure of health in estuarine and coastal waters, which has attracted more research attention in recent years. Oxygen deficiency can degrade an ecosystem by destroying the bottom fauna habitats, therefore, altering the food web and aquatic ecosystem with undesirable consequences in estuaries and coasts $[13,14]$. On the one hand, if the estuarine stratification increases, the vertical DO exchange is reduced; consequently, the bottom DO condition becomes worse [15-17]. On the other hand, when the strength of estuarine gravitational circulation increases, there is less time for DO consumption as water parcels travel upriver $[13,16,17]$. Gravitational circulation is one of the key mechanisms of an estuary that transports freshwater and pollutants out of the estuary near the surface and transport waters and pollutants from the outside to the estuary near the bottom $[1,2,6]$. The classical estuary circulation theory shows that a depth change has a significant impact on the strength of the gravitational circulation $[1,2,5,6]$. A change in gravitational circulation due to channel deepening changes estuarine residence time $[16,18]$, which can have a profound impact on estuarine hydrodynamics and the ecosystem [19-21]. Although channel deepening improves navigation, it can cause unexpected consequences to the environment and ecosystem. Because the rate of global sea-level rise is increasing more rapidly than in the past [22], this can put more pressure on the ecosystem, similar to channel deepening [4]. Therefore, an investigation of the influences of channel deepening and sea-level rise on the ecosystem is highly warranted.

Human interventions, such as widening and deepening of estuarine and tidal river channels, can impact the distribution of suspended particulate matters, with important ecological ramifications including deteriorated light, primary production, and oxygen conditions. Previous research results have shown that tidal channel deepening could led to a shift of trapping locations of suspended particulate matter, which could lead to a significant oxygen deficit $[8,9,20,21]$. After deepening of the navigation channel of the Elbe Estuary, it was found that enhanced oxygen deficiencies occurred and there was a permanent loss in the capacity of branches for reaeration of the open water [23]. An additional study found that an increase in tidal range and non-tidal circulation resulted in salinity increase and attendant consequences to the estuary's ecology after the channel deepening in Tampa Bay [24].

It is commonly thought that an increase in channel depth results in increases in both stratification and gravitational circulation. However, recent studies have shown that a change in channel depth and sea-level rise can alter the tidal range, thus altering mixing processes [18]. A change in tidal range is not uniform along an estuary and depends on both the length and depth of the estuary [4]. The impact of nonlinear effect of tidal range on DO has not been fully studied.

Previous studies have indicated that channel deepening could affect both biochemical and dynamic conditions $[8,9,24]$, consequently, affecting DO condition. However, the impact of channel deepening and sea-level rise on hydrodynamics and DO has not been fully studied for estuaries with complex geometry, which is the focus of this study. The James River, a western tributary of the Chesapeake Bay, USA was used as a prototype estuary to explore this impact. The James River is a typical partially mixed estuary [2]. To continue port development, channel deepening in the lower James River and Elizabeth River has been planned. One of the concerns is whether the increase in water depth could affect the DO and preserve ecological integrity because DO is one of the important indicators of the health of the aquatic ecosystem. Although the James River receives massive discharges of nutrients, DO conditions remain above the hypoxia level due to its strong gravitational circulation that transports a significant amount of high DO water from Chesapeake Bay into the James River [16]. Here, we address the potential changes in stratification and gravitational circulation and their impacts on DO levels in the James River.

To address the problem, we investigated the changes in hydrodynamic fields, including tidal rage, salinity, and stratification. Additionally, we investigated the changes in transport timescales because hydrodynamic transport characteristics of an estuary can be quantified by transport properties, including residence time, flushing time, and vertical transport time [25-30]. As timescales provide a 
common measure of hydrodynamics, hydrodynamics for different estuaries can be compared using timescales [25,31]. For example, many studies have used water age to diagnose the vertical transport process $[25,32,33]$. These timescales provide measures of characteristics of estuarine transport of pollutants, nutrient retention, DO aeration, and algal bloom $[25,26,30,31]$. To quantify the changes in stratification and estuarine circulation for different channel deepening scenarios, the vertical and saltwater transport times of the James River were compared using a three-dimensional (3D) numerical model to diagnose variations of the aquatic environmental condition. Although the investigation was conducted for the James River, the approach and results are applicable to other partially mixed estuaries.

\section{Study Area}

The James River is a western tributary of the Chesapeake Bay, USA (Figure 1). It is about $160.0 \mathrm{~km}$ long and has a width that ranges from $300 \mathrm{~m}$ at its upstream boundary to $6 \mathrm{~km}$ at its downstream boundary with a mean depth of $3.76 \mathrm{~m}$. The tidal range is about $0.74 \mathrm{~m}$ at Sewells Point near the mouth. The average freshwater discharge is $226 \mathrm{~m}^{3} \mathrm{~s}^{-1}$ [34]. An abrupt bend in the river occurs at Newport News Point, approximately $10.5 \mathrm{~km}$ from its mouth, where the orientation of the river changes from northeast-southwest in the lower river to southeast-northwest in the upper river. The horizontal salinity gradients are usually larger near the upper mesohaline of the river where the freshwater meets saltwater. The denser, more saline bottom waters enter the James River from the Chesapeake Bay and flow upstream, while the less dense surface waters, dominated by freshwater inflow, flow downstream toward the Bay [1]. The Elizabeth River is one of the branches of the James River near the mouth of the river, and is approximately $32 \mathrm{~km}$ long. The existing shipping channel, with a depth of $10 \mathrm{~m}$, extends from the mouth to the upstream. The unique geometry of the James River and Elizabeth River results in complex dynamic fields in this system.

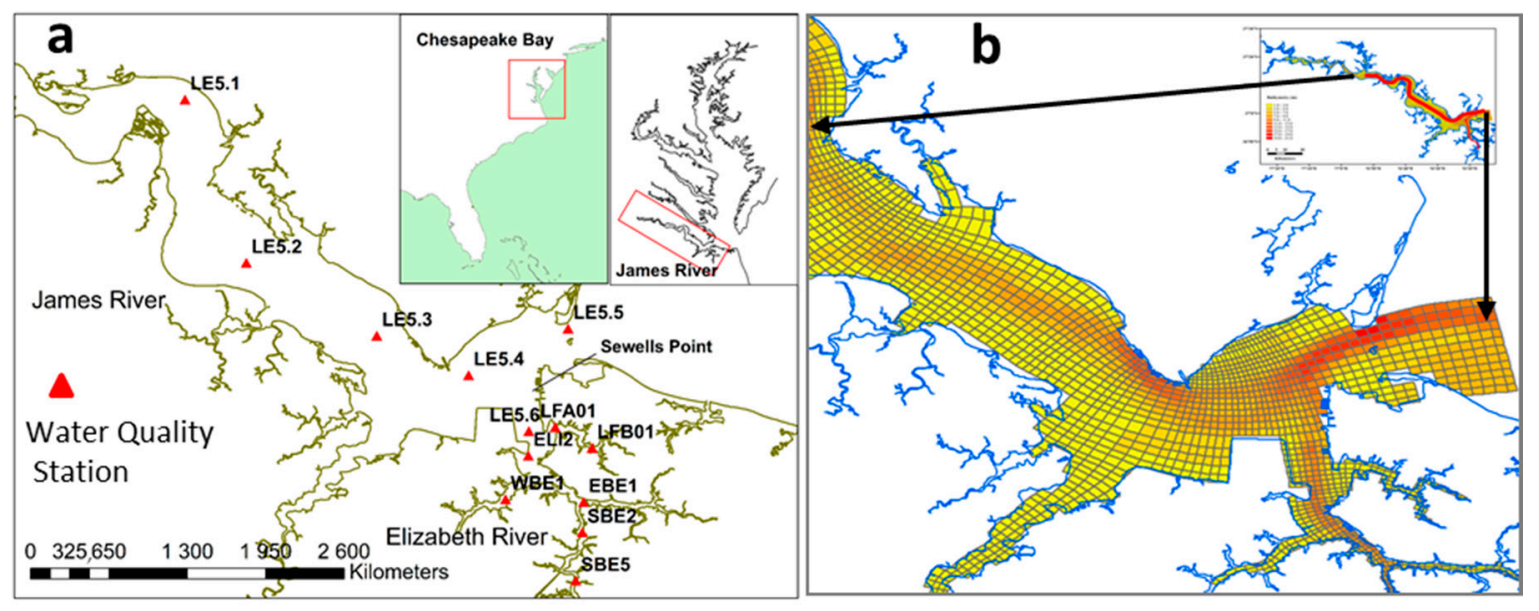

Figure 1. Location maps of James River and diagram of the numerical model grid. (a) area map with water quality monitoring stations (triangles are observation stations for DO verification), (b) model grid (the red line, insert figure denotes the area of channel deepening).

\section{Methods}

\subsection{Numerical Model}

The three-dimensional Environmental Fluid Dynamic Code (EFDC) model was used for the James River and its tributaries. The EFDC model is a general hydrodynamic and water quality model that solves three-dimensional, time-dependent flows governed by hydrostatic primitive equations [35-37]. The model uses curvilinear, orthogonal horizontal coordinates, and sigma vertical coordinates to represent water body. The modified Mellor and Yamada [38] level 2.5 turbulence closure model [39] is implemented in the model. A eutrophication model is coupled to the hydrodynamic model $[37,40]$. It has become one of the most widely used numerical models for estuaries [41]. 
The model grid and computational domain of this study are presented in Figure 1 . The model grid cells (ranging from 300 to $1200 \mathrm{~m}$ ) were designed to follow the main channel of the James River. High resolution was placed on the main stem of the river $(\sim 300 \times 400 \mathrm{~m})$ to obtain the best representation of the topography in this area. There are 3066 water cells in the horizontal plane and eight layers in the vertical direction. Daily river discharges and nutrients from the upstream and lateral watersheds were obtained from the James River watershed model developed by the Chesapeake Bay program [40]. The three most important upstream freshwater discharges are from Richmond, Appomattox River, and Chickahominy River, respectively. The wind forcing data were obtained from the Norfolk International Airports located near the Sewells Point station near the mouth. Hourly wind forcing, surface pressure, humidity, and solar radiation obtained from the meteorological data were used for temperature simulations. The hourly tide, temperature, and salinity data obtained from the 3D model of the Chesapeake Bay program [14] were used for the open boundary conditions. The model simulation period was from 2005 to 2013 with a time step of $20 \mathrm{~s}$. The modeled surface elevations are within 0.5 root mean square error (RMSE) that is less than $0.15 \mathrm{~m}$, and the model skills for current simulations range from 0.48 to 0.83 [34].

The three-dimensional eutrophication model simulated winter and summer assemblages of phytoplankton, particulate and dissolved organic nitrogen (PON and DON), phosphorus (POP and DOP), dissolved inorganic nitrogen $\left(\mathrm{NH}_{4}, \mathrm{NO}_{2}, \mathrm{NO}_{3}\right)$, dissolved phosphate $\left(\mathrm{PO}_{4}\right)$, and DO. A bottom sediment process model is coupled to the water column to simulate mineralization and bottom fluxes of $\mathrm{NH}_{4}, \mathrm{NO}_{3}, \mathrm{PO}_{4}$, and sediment oxygen demand (SOD) [37]. Open boundary condition of daily concentration of each eutrophication state variable was obtained from the Chesapeake Bay program's water quality model [14]. The water quality model was used to evaluate the DO condition. The water quality models were calibrated and verified from 2005 to 2013 [40]. The monthly water quality state variables were collected by the Virginia Department of Quality from 2005 to 2013 at stations along the main channel of the James River and Elizabeth River. Observations included phytoplankton (chl a), nitrogen and phosphorus (total, organic, and inorganic), and DO, together with environment variables including salinity, temperature, and total suspended solids, available at Chesapeake Bay Program (https://www.chesapeakebay.net/). These variables were used for model calibration. The calibration of water quality model focused on phytoplankton, which was the key state variable. Both light attenuation and temperature dependent functions for phytoplankton growth were estimated based on monthly observation data. The major parameters calibrated were growth, respiration, mortality, and settling rates. Growth rate determines the primary production. Respiration, mortality, and settling rates are important to control nutrient recycle in both water column and bottom sediment. The James River was divided into 3 major regions corresponding to tidal freshwater, mesohaline, and polyhaline. Parameters were allowed to vary at different regions to account for different phytoplankton species in each region [40].

\subsection{Transport Time and Bottom Dissolved Oxygen (DO)}

The impacts of dynamics on DO in an estuary are mainly caused by DO aeration through surface and bottom exchange processes [15], and gravitational circulation that changes both DO supply and DO consumption near the bottom [16,17]. Shen et al. [25] proposed a simplified model to quantify it. For a partially mixed estuary, the transport process can be described by a two-layer model. Assuming steady state for tidally averaged flow, the lower layer oxygen for a uniform estuary is governed by the following equation [16,25]:

$$
u \frac{d O}{d x}=\frac{k_{z}}{H} \frac{\left(O_{s}-O\right)}{d}-B
$$

where $u$ is the constant mean bottom inflow velocity due to gravitational circulation, $O_{s}$ and $O$ are the DO concentrations $(\mathrm{mg} / \mathrm{L})$ in the surface layer and bottom layer, $k_{z}$ is the vertical exchange rate $\left(\mathrm{m}^{2} \mathrm{~s}^{-1}\right)$ between the surface and bottom layers that parameterizes the overall exchange between surface and bottom layers including turbulent mixing and lateral circulation induced mixing, $H(\mathrm{~m})$ is 
the bottom layer thickness, $d(\mathrm{~m})$ is the distance between the middle of two layers, and $B$ is the total DO consumption rate $\left(\mathrm{g} \mathrm{O}_{2} \mathrm{~m}^{-3} \mathrm{~d}^{-1}\right)$ including both water column and sediment oxygen demand. Letting $D=O_{s^{-}}-O$ as DO deficit, and applying boundary condition $D=D_{0}$ at $x=0$, Equation (1) can be solved and expressed as [25]:

$$
\frac{O}{O_{s}}=1-\frac{\tau_{v}}{\tau_{b}}\left(1-e^{-\frac{\tau_{e}}{\tau_{v}}}\right)-\frac{D_{0}}{O_{s}} e^{-\frac{\tau_{e}}{\tau_{v}}}
$$

where $\tau_{e}=x / u$ is the longitudinal transport timescale indicating the travel time of gravitational circulation, $\tau_{v}=H d / k_{z}$ is the vertical exchange timescale, and $\tau_{b}=O_{s} / B$ is the timescale of the biological oxygen consumption. Transport time $\tau_{v}$ is the vertical exchange timescale that is the average time required for the vertical transport of a water parcel between two layers. The transport includes vertical mixing, lateral circulation, and vertical advection and is the elapsed time of the DO when it leaves the surface and reaches the bottom. $\tau_{e}$ is the average time required for the water parcel to be transported from the mouth to any location of concern, which measures transport time of the estuarine gradational circulation and is referred as saltwater age hereafter.

If DO at the open boundary of the estuary is equal to the saturation DO, Equation (2) can be expressed by the two dimensionless parameters of $\tau_{b}^{*}$ and $\tau_{e}^{*}$ as:

$$
\frac{O}{O_{s}}=1-\frac{1}{\tau_{b}^{*}}\left(1-e^{-\tau_{e}^{*}}\right)
$$

where $\tau_{b}^{*}=\tau_{b} / \tau_{v}$ is the oxygen consumption time $\left(\tau_{b}\right)$ normalized by vertical exchange time $\left(\tau_{v}\right)$, which quantifies the competition of total biochemical oxygen consumption time; and $\tau_{e}^{*}=\tau_{e} / \tau_{v}$, which is the transport timescale of gravitational circulation $\left(\tau_{e}\right)$ normalized by $\left(\tau_{v}\right)$. Because gravitational circulation is related to the stratification, a change in stratification, or $\tau_{v}$, will result in a change in $\tau_{e}$. The ratio determines the impact and the competition between two processes. Equation (3) is formulated using a Lagrangian perspective, with both the biochemical DO consumption rate and the physical processes quantified by timescales [25]. It can be seen that the impact of dynamics on DO can be compared by these two non-dimensional timescales for different estuaries if these timescales are known.

Both transport timescales, $\tau_{e}$ and $\tau_{v}$, can be obtained by computing transport times of saltwater age and surface water age $[18,25,27,28]$. The transport time represents the elapsed time since the water was last in contact with the tracer source $[27,28,42]$. When a conservative tracer is released at a location (e.g., open boundary or surface), the resulting water age at any location represents the transport time required for the water parcel to be transported from the release location to the current location. It represents the transport timescale from its source to the location of concern [27]. The transport timescale is calculated as the mean water age, which is governed by the following equations:

$$
\begin{gathered}
\frac{\partial C(t, x, y, z)}{\partial t}+\nabla \times(\vec{u} a(t, x, y, z)-K \nabla \times C(t, x, y, z))=0 \\
\frac{\partial \alpha(t, x, y, z)}{\partial t}+\nabla \times(\vec{u} \alpha(t, x, y, z)-K \nabla \times \alpha(t, x, y, z))=C(t, x, y, z)
\end{gathered}
$$

The mean water age can be calculated as follows:

$$
a(t, x, y, z)=\alpha(t, x, y, z) / C(t, x, y, z)
$$

where $\nabla=\vec{i} \frac{\partial}{\partial x}+\vec{j} \frac{\partial}{\partial y}+\vec{k} \frac{\partial}{\partial z}, C(t, x, z)$ is the tracer concentration, $\alpha(t, x, y, z)$ is age concentration, $\vec{u}$ is the velocity field, and $K$ is the diffusivity tensor. A modeled conservative tracer was used to calculate the transport timescales of the estuary based on Equations (4) to (6). The tracer was continuously released from the open boundary of the James River or at the surface, respectively, corresponding to 
saltwater age and vertical exchange time. The age concentration was set to zero at the release location. The "no flux" condition was used at the bottom for computing vertical exchange time [32,42].

\subsection{Channel Deepening and Sea-Level Rise Simulations}

We investigated the impact of channel deepening in the James River on the DO through a series of numerical experiments. The model experiments included three simulations with channel deepening of 1.0, 2.0, and $3.0 \mathrm{~m}$, respectively, for the channel from the mouth to the upper mesohaline of the James River (Figure 1b). The selected values were based on Army Corps of Engineers current and projected future channel deepening. These 3 experiments were defined as Scenarios E01, E02, and E03 (Table 1). For all these experiments, freshwater discharges and salinity at the open boundary were unchanged. Both biological parameters and nutrient loadings from watershed, and open boundary conditions were unchanged. The baseline of the simulation was denoted as E00. The channel along the central shipping lane was uniformly increased. The width of the deep channel was unchanged, which was about $1.0 \mathrm{~km}$. In order to compare the channel deepening with sea-level rise, the fourth simulation with an increase of mean sea level of $1.0 \mathrm{~m}$ was conducted, which was denoted as Scenario E04 (Table 1). A $1.0 \mathrm{~m}$ increase in sea level has been projected in the Chesapeake Bay region by 2100, based on Climate Change Science Program [18,22], which, currently, has been used for projected sea-level rise as of 2100 [43]. For the sea-level rise simulation, a mean sea level of $1.0 \mathrm{~m}$ was added as a subtidal at the open boundary. The model reached equilibrium within about 3-4 months. The shoreline of the James River is mixed with mostly hardening shoreline and living shoreline with beaches and fringing marshes. A recent study on the likelihood of shore protection along the Virginia coast showed that shoreline protection is certain for the major portion of the James River, because the elevation of the low-lying area is well above sea level with projected sea-level rise by $2100[43,44]$. There is only a small portion of the area where shore protection is likely. Although the current model does not include the low-lying area, the James River is suitable for studying the impact of a sea-level rise of $1.0 \mathrm{~m}$ in the James River.

Table 1. Summary of numerical experiments.

\begin{tabular}{ccc}
\hline Scenario & $\begin{array}{c}\text { Channel Deepening } \\
(\mathbf{m})\end{array}$ & $\begin{array}{c}\text { Boundary Elevation } \\
\text { Increase }(\mathbf{m})\end{array}$ \\
\hline E00 & 0 & 0 \\
E01 & 1 & 0 \\
E02 & 2 & 0 \\
E03 & 3 & 0 \\
E04 & 0 & 1 \\
\hline
\end{tabular}

\subsection{Vertical Stratification}

The channel deepening impacts on the vertical salinity distribution, and thereby influences the vertical stratification. The vertical stratification is the foremost concern as it is highly correlated to the hypoxia. Numerous studies have documented a high correlation between the estuary stratification and hypoxia $[13,15,45]$. Vertical stratification inhibits mixing that would otherwise replenish the deeper water with oxygen [29]. To quantify the stratification, the Brunt-Vaisala frequency was calculated [46] to measure the stratification strength:

$$
N^{2}=\frac{g}{\rho} \frac{\partial \rho}{\partial z}
$$

where $g$ is the gravitational constant and $\rho$ is the water density (in $\mathrm{kg} \mathrm{m}^{-3}$ ). The frequency was computed at each model grid along the main channel, shown in Figure $1 \mathrm{~b}$, and averaged throughout the results of the main stem of the James River. 


\subsection{Model Validation}

The model was effectively calibrated for both hydrodynamics and water quality state variables. The model calibration results showed that the model could effectively reproduce water quality state variables [40]. As the focus of this study is DO, comparisons of DO between observations and model-simulated results were plotted in a Taylor diagram [47], shown in Figure 2 and some statistics are listed in Table 2. The values of the correlation coefficients at different stations in the James River varied from 0.94 to 0.96 (with a 95\% confidence level) and in the Elizabeth River range from 0.85 to 0.94 (with a 95\% confidence level). The modeled DO had a very small standard deviation suggesting temporal variation was close to that of the observations. Station LE5.1 was used as the reference site, and the RMSE was about 0.721 at that station. The RMSE values at other stations were about equal to or less than 0.5 of the standard deviation of the referenced RMSE. These results indicated that the model was reliable for simulating the seasonal variation and model experiments in this study.

\section{James River lower stream}

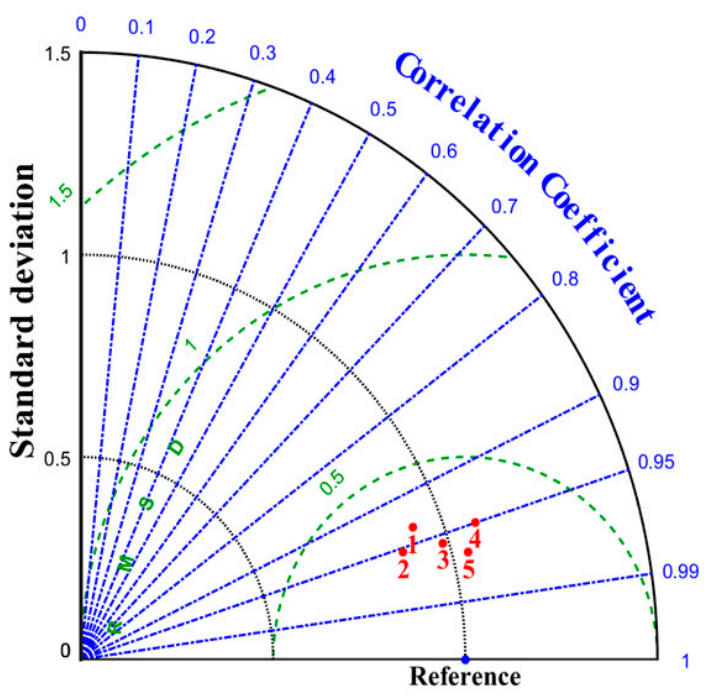

\section{Elizabeth River}

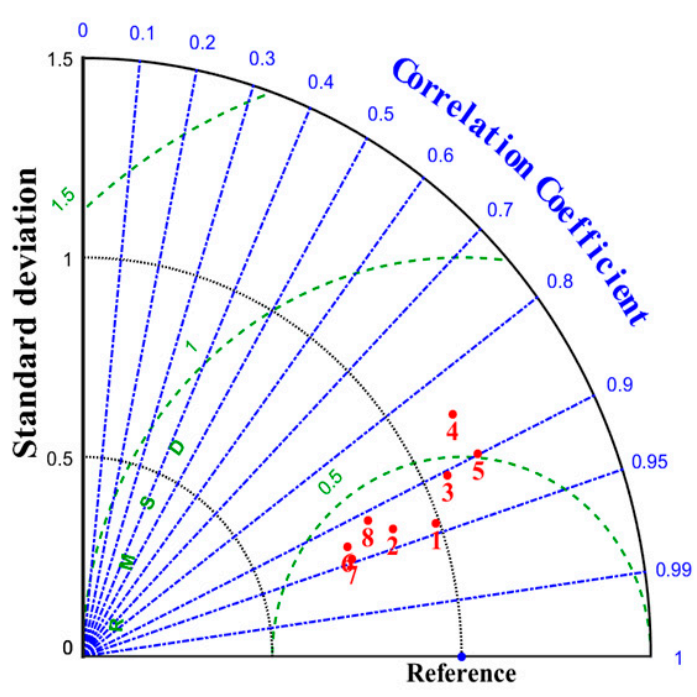

Figure 2. Taylor diagram displaying the statistical comparison of model predictions and observations of 13 monitoring stations of the dissolved oxygen, the monitoring station are James River (LE5.1, LE5.2, LE5.3, LE5.4, and LE5.5) and Elizabeth River (LE5.6, ELI2, EBE1, SBE2, SBE5, LFA01, LFB01, and WBE1).

Table 2. A summary of statistics showing the skill of the James River water quality model *.

\begin{tabular}{cccccc}
\hline State Variable & ME & AME & RE & RMSE & R \\
\hline $\mathrm{Chl} \mathrm{a}(\mu \mathrm{g} / \mathrm{L})$ & 0.283 & 5.559 & 0.658 & 10.119 & 0.441 \\
$\mathrm{NH}_{4}(\mathrm{mg} / \mathrm{L})$ & -0.081 & 0.112 & 0.635 & 0.146 & 0.372 \\
$\mathrm{DIN}(\mathrm{mg} / \mathrm{L})$ & -0.004 & 0.010 & 0.367 & 0.015 & 0.760 \\
$\mathrm{NO}_{2}+\mathrm{NO}_{3}(\mathrm{mg} / \mathrm{L})$ & -0.025 & 0.041 & 0.700 & 0.057 & 0.343 \\
$\mathrm{PO}_{4}(\mathrm{mg} / \mathrm{L})$ & -0.052 & 0.073 & 0.689 & 0.104 & 0.428 \\
$\mathrm{DO}(\mathrm{mg} / \mathrm{L})$ & 0.095 & 0.526 & 0.066 & 0.721 & 0.959 \\
\hline
\end{tabular}

* ME, mean error; AME, absolute error; RE, Relative error; RMSE, root mean square error; R, correlation coefficient. Statistics are estimated for Stations LE5.1, LE5.2, LE5.3, LE5.4, LE5.5 for simulation period.

\section{Results}

\subsection{Change in DO}

The DO in the James River varies seasonally over a year [16]. We compared changes in seasonal DO (spring and summer) that had been used for water quality condition assessment in the Chesapeake 
Bay [40]. The spring season spans from March to May and the summer season spans from June to August. In the spring season, depth-averaged DO decreases as the channel depth increases. The value of the mean DO decreases from 7.77 to $7.63 \mathrm{mg} / \mathrm{L}$ as compared the baseline (E00) to the scenario with a deepening of $3 \mathrm{~m}$ (E03) (average of Stations LE5.1, LE5.2, LE5.3, LE5.4, and LE5.5). For the bottom $\mathrm{DO}$, its value decreases from 7.66 to $7.46 \mathrm{mg} / \mathrm{L}$ as compared with the baseline (E00) to scenario (E03) (Table 3). The vertical mean DO value decreases to 7.53 from $7.77 \mathrm{mg} / \mathrm{L}$ and the bottom DO value decreases to 7.37 from $7.66 \mathrm{mg} / \mathrm{L}$ when sea-level rise of $1.0 \mathrm{~m}$ (E04) (Table 3).

Table 3. The comparison of dissolved oxygen results of the numerical experiment of the channel deepening in the spring and summer season.

\begin{tabular}{lcccccccccc}
\hline & \multicolumn{3}{c}{ Spring } & \multicolumn{5}{c}{ Summer } \\
\hline \multicolumn{1}{c}{ Variables } & E00 & E01 & E02 & E03 & E04 & E00 & E01 & E02 & E03 & E04 \\
\hline Mean (mg/L) & 7.77 & 7.72 & 7.68 & 7.63 & 7.53 & 6.28 & 6.22 & 6.18 & 6.15 & 6.05 \\
Bottom (mg/L) & 7.66 & 7.58 & 7.53 & 7.46 & 7.37 & 6.11 & 6.01 & 5.95 & 5.89 & 5.81 \\
Mean difference (mg/L) & & -0.05 & -0.09 & -0.14 & -0.24 & & -0.07 & -0.10 & -0.13 & -0.24 \\
Bottom difference (mg/L) & & -0.07 & -0.13 & -0.20 & -0.29 & & -0.10 & -0.16 & -0.22 & -0.29 \\
Relative mean difference (\%) & & -0.70 & -1.21 & -1.75 & -3.09 & & -1.05 & -1.66 & -2.12 & -3.75 \\
Relative bottom & & -0.95 & -1.73 & -2.62 & -3.77 & & -1.59 & -2.64 & -3.58 & -4.82 \\
difference (\%) & & & & & & & & & & \\
\hline
\end{tabular}

DO in the summer season is low as compared with that in the spring in the James River. In the summer season, depth-averaged DO decreases as the channel depth increases. The value of the mean DO decreases from 6.28 to $6.15 \mathrm{mg} / \mathrm{L}$ as compared with the baseline (E00) to the scenario deepening $3 \mathrm{~m}$ (E03). For bottom DO, its value changes from 6.11 to $5.89 \mathrm{mg} / \mathrm{L}$ as compared the baseline (E00) to the scenario (E03) (Table 3). It can be seen that the mean DO levels do not change dramatically in the estuary, either with an increase in channel depth of $3 \mathrm{~m}$ or an increase in sea level of $1 \mathrm{~m}$ (E04). The vertical mean DO value decreases to 6.05 from $6.28 \mathrm{mg} / \mathrm{L}$ and the bottom $\mathrm{DO}$ value decreases to 5.81 from $6.11 \mathrm{mg} / \mathrm{L}$ for the sea-level rise scenario (E04) (Table 3).

Because the biological parameters and nutrient loadings were unchanged during these simulations, it appeared that the change in hydrodynamics was one of the main reasons causing DO change, although hydrodynamics might also affect biological processes. When water depth increases, the vertical mixing decreases, resulting in a decrease in bottom DO. On the one hand, the minor change of DO could be due to the increase of gravitational circulation as previous studies have suggested [16]. On the other hand, it could also be due to the change of tidal range, which alters the mixing processes. We discuss these in the following sections.

\subsection{Change in Tidal Amplitude and Salinity Intrusion}

To understand the influence of hydrodynamic conditions on DO, multiple key parameters were investigated. The tidal characteristics are important for estuarine dynamics. The change in tidal range for different scenarios was investigated. The dominant $\mathrm{M}_{2}$ tidal constituent was selected to examine the tidal amplitude variation along the estuary. Figure 3 a illustrates the variation of the $\mathrm{M}_{2}$ tide amplitude as the channel depth increases and sea-level rises, clearly indicating that the amplitude of the $\mathrm{M}_{2}$ tidal constituent decreases slightly before the nodal point and increases over most of the James River for both channel deepening and sea-level rise scenarios. The increase is amplified toward the upstream. The tidal range, measured at a distance of $125 \mathrm{~km}$ from the mouth, increases from $0.6 \mathrm{~m}$ to $0.75,0.85$, and $0.98 \mathrm{~m}$, respectively, for channel deepening of 1.0, 2.0, and $3.0 \mathrm{~m}$. Tidal range, measured at a distance of about $30 \mathrm{~km}$ from the mouth, decreases from 0.02 to $0.10 \mathrm{~m}$ for different channel deepening cases. The tidal rage increase due to sea-level rise is evident, which is much different from that due to channel deepening. The tidal range increases about $36 \%$ near the nodal point and the $\mathrm{M}_{2}$ tide varies from 0.65 to $0.85 \mathrm{~m}$ (Figure 3a), which agrees with results of Du et al. [4]. The distribution of tidal range is the result of the superposition of the incoming tide and the reflected tide and depends on the depth, 
length, and geometry (channel convergence) $[4,48]$. An increase in tidal range towards upstream, as associated with channel deepening, is largely due to the reduction of bottom friction [3], while a decrease in tidal range before nodal point is mainly caused by the interaction of incoming and reflected tidal waves. For the sea-level rise scenario, the mean depth is changed by $1.0 \mathrm{~m}$. The change in mean water depth due to sea-level rise is more pronounced as compared with only channel deepening. As a result, the bottom friction decreases in the entire estuary, resulting in an increase in tidal range.
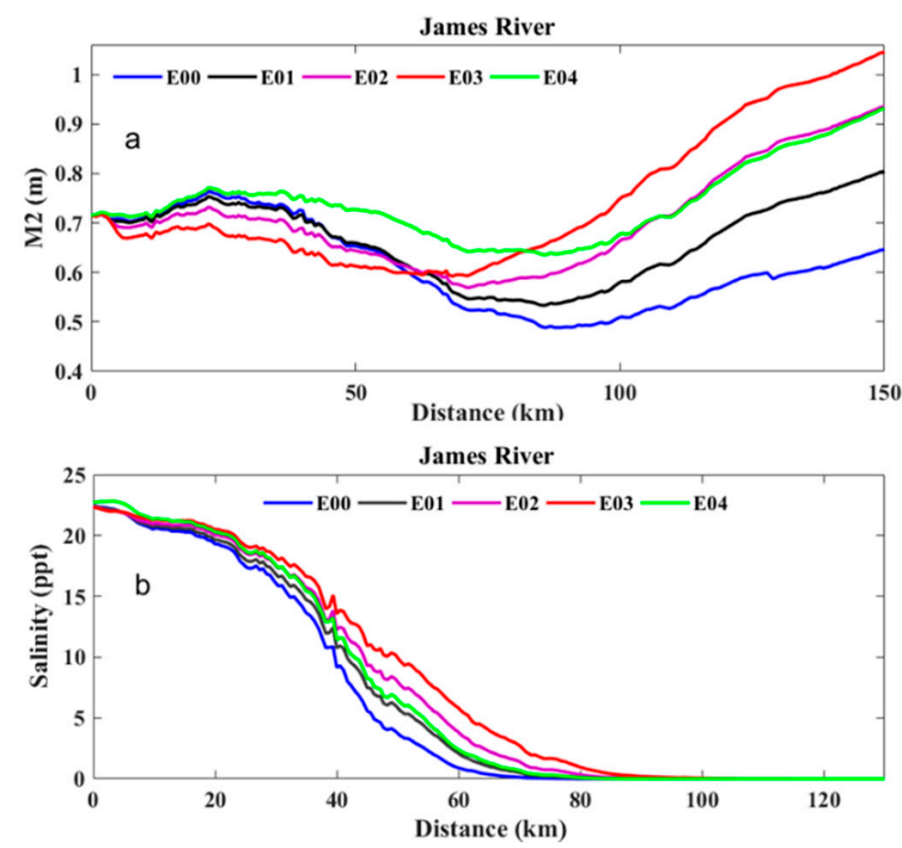

Figure 3. Modeled $\mathrm{M}_{2}$ tide range and annual mean salinity along the channel under present, channel deepening, and future sea-level conditions. (a) Tidal range; (b) Salinity intrusion.

One of the impacts of the channel deepening is that it can increase salt intrusion toward the upstream, which is an indicator of an increase in gravitational circulation. To demonstrate the variation of salinity intrusion after the channel deepening, the yearly mean salinity along the channel was plotted. The result showed that the salinity migrates further upstream when the channel depth increases. The salinity migrates further upstream, i.e., about $10 \mathrm{~km}$, when the mean channel depth increases from 9.38 to $12.31 \mathrm{~m}$ (Figure $3 \mathrm{~b}$ ). The salinity migrates further upstream, i.e., about $5 \mathrm{~km}$, in response to the potential sea-level rise of $1 \mathrm{~m}$ at the James River mouth (Figure $3 \mathrm{~b}$ ), which agrees with the result of a previous study [43].

\subsection{Change in Stratification}

The Brunt-Vaisala frequency was computed for each scenario. To illustrate the seasonal variations of the stratification, 2011 was chosen to show the monthly mean results (Figure 4). A larger stratification occurs during the winter to spring and weaker stratification occurs during the summer. It is clearly seen that the stratification is strengthened when channel depth increases or sea-level rises. The estuary is sensitive to a change in channel depth. The increase in stratification with depth increase is more prominent during the spring season when the estuary experiences high stratification due to the large freshwater discharge in the James River (Figure 4). The change in stratification for the sea-level rise case is closer to the channel deepening by $1.0 \mathrm{~m}$. It can be seen that the stratification increases for the sea-level rise case even when the tidal range increases, which suggests that depth increase plays an important role in the decrease in eddy viscosity. 


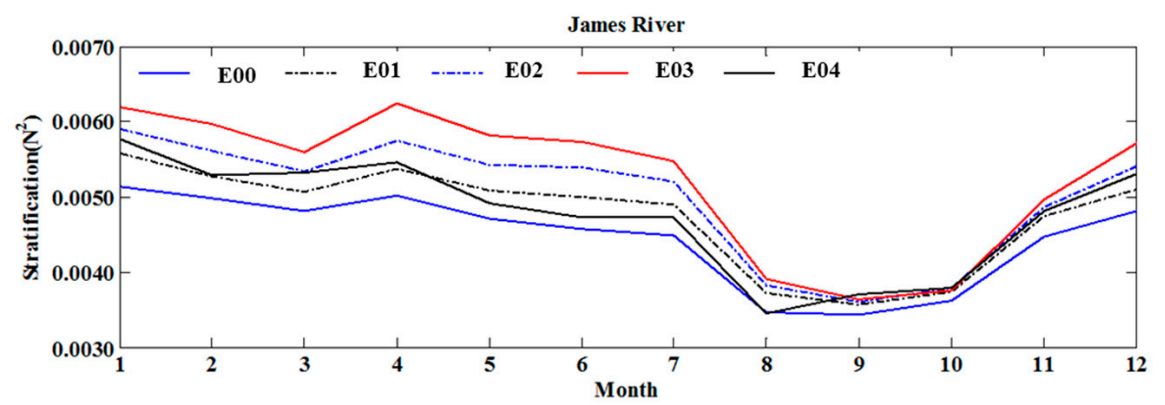

Figure 4. Variation of the seasonal mean salinity stratification strength (maximum $\mathrm{N}^{2}$ in $\mathrm{s}^{-2}$ ) with respect to channel deepening and sea-level rise.

\subsection{Change in Gravitational Circulation}

An alteration of bathymetry in the channel changes the mean horizontal salinity gradient and tidal mixing. These changes result in a change in gravitational circulation. According to the classical estuarine circulation theory, gravitational circulation $\left(U_{E}\right)$ can be scaled as $U_{E}=g \overline{\beta S_{x}} H^{3} /\left(48 K_{M}\right)$ [6]. The estuarine circulation increases when either $\mathrm{H}$ or the horizontal pressure gradient (estimated by $\overline{S_{x}}$ ) increases, and it decreases when the vertical eddy viscosity $K_{M}$ increases. Although this classical formulation does not account for nonlinear and wind effects [49], it provides insights into what factors dominate changes of gravitational circulation.

The averaged horizontal salinity gradient and vertical eddy viscosity were both calculated for the summer season. The results show that a change in channel depth results in a change in the horizontal salinity gradient and the vertical eddy viscosity. The horizontal salinity gradient decreases from $4.62 \times 10^{-4}$ to $3.52 \times 10^{-4}$ psu m$^{-1}$ when the mean channel depth increases from 9.38 to $12.31 \mathrm{~m}$ (Table 4). The horizontal gradient of salinity changes to $4.35 \times 10^{-4} \mathrm{psu} \mathrm{m}^{-1}$ when sea- level rises by one meter. The gradient decrease is less than that of channel deepening. The vertical eddy viscosity decreases from 32.95 to $27.68 \mathrm{~cm}^{2} \mathrm{~s}^{-1}$ as the mean channel depth changes from 9.38 to $12.31 \mathrm{~m}$. However, the vertical eddy viscosity decreases slightly for sea-level rise cases, which is mainly due to an increase in tidal range (Table 4).

Table 4. The comparison of the gravitational circulation strength after the channel deepening.

\begin{tabular}{lccccc}
\hline \multicolumn{1}{c}{ Variables } & E00 & E01 & E02 & E03 & E04 \\
\hline $\mathrm{H}(\mathrm{m})$ & 9.38 & 10.35 & 11.33 & 12.31 & 10.38 \\
Salinity gradient $\left(10^{-4} \mathrm{psu} \mathrm{m}^{-1}\right)$ & 4.62 & 4.31 & 3.91 & 3.52 & 4.35 \\
Eddy viscosity $\left(\mathrm{cm}^{2} \mathrm{~s}^{-1}\right)$ & 32.95 & 30.44 & 28.09 & 27.68 & 30.25 \\
Circulation strength $\left(\mathrm{ms}^{-1}\right)$ & 0.018 & 0.025 & 0.032 & 0.037 & 0.025 \\
\hline
\end{tabular}

Gravitational circulation changes when channel depth increases. The averaged gravitational circulation strength increases from 0.018 to $0.037 \mathrm{~m} \mathrm{~s}^{-1}$ when the mean channel depth increases from 9.38 to $12.31 \mathrm{~m}$ (Table 4 ). The gravitational circulation strength increases, from the present condition, from 0.018 to $0.025 \mathrm{~m} \mathrm{~s}^{-1}$ when the sea-level rises by one meter. It indicates that depth is the dominant parameter as gravitational circulation is proportional to the cube of the depth [6].

An increase in gravitational circulation indicates faster water movement, which allows less time for DO to be consumed, as a water parcel travels upstream [16,17]. However, these changes are site specific and do not directly link to DO, and they are difficult to compare for different scenarios or estuaries. To measure the change in gravitational circulation, the timescale was computed for a better understanding of the changes. 


\subsection{Change in Saltwater Age along the Transect}

The impact of estuarine circulation has an accumulative effect on DO. The strength of the gravitational circulation contributes highly on the bottom DO as it can transport more DO-enriched water from outside of the estuary. In addition, the fast moving incoming water reduces $\mathrm{DO}$ consumption. However, the accumulative effect of gravitational circulation is difficult to quantify. To understand its impact, the saltwater age was used as a measure for evaluating circulation change between the existing condition and scenarios. This timescale measures the overall change in the transport processes of saltwater as channel depth changes [50]. A transect along the mainstem of the James River was selected to demonstrate the variation of transport processes after channel deepening. Saltwater age decreases with an increase in channel depth. For example, at the location of $45 \mathrm{~km}$ from the James River mouth, the saltwater age decreases from 25 to 22 days (Figure 5a), which indicates the strength of the gravitational circulation increases as the channel depth increases. The results are consistent with the change in the gravitational circulation (Table 4). This provides the benefit of elevating the DO level inside the estuary. Unlike channel deepening scenarios, the saltwater age does not change much downstream but increases after $40 \mathrm{~km}$ when the sea-level rises $1 \mathrm{~m}$, which suggests a decrease in circulation effect due to a change in water volume and an increase in tidal range. The difference between the sea-level rise scenario and channel deepening is that the water depth increases in the sea-level rise scenario everywhere by almost $1.0 \mathrm{~m}$, and both the mean depth and total volume increase by $27 \%$.
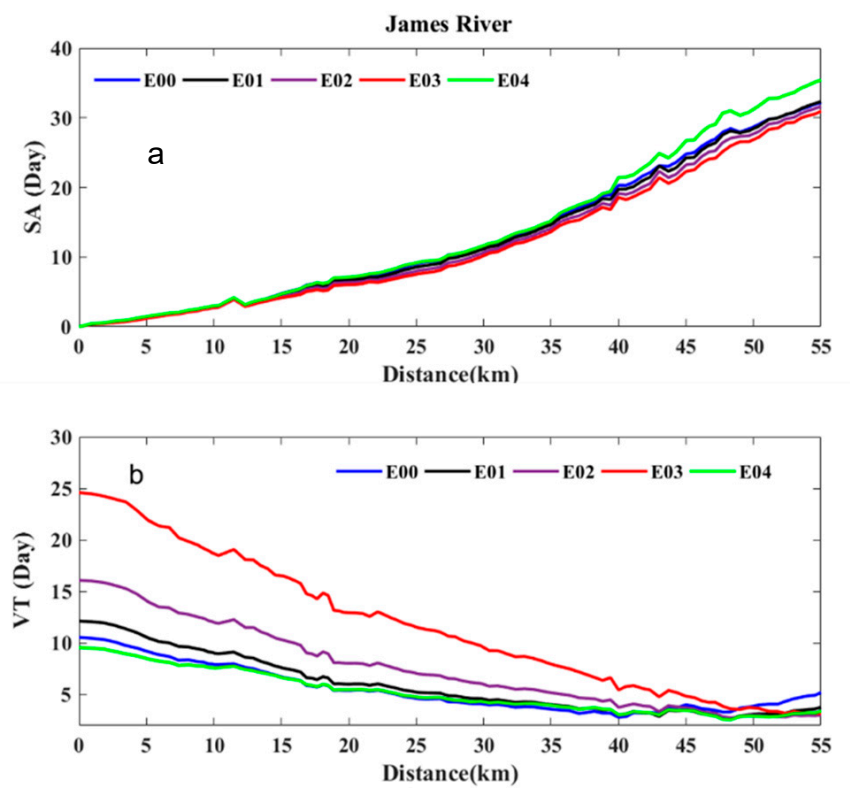

Figure 5. Variation of the annually averaged saltwater age and the vertical exchange time along the channel with respect to channel deepening and the sea-level rise. (a) Saltwater age; (b) Vertical exchange time.

\subsection{Change in Vertical Exchange Time along Transect}

An increase in channel depth can decrease tidal mixing and increase stratification in the lower mesohaline and polyhaline regions. The increase in the stratification can weaken the vertical exchange at the same time. By using the vertical exchange time, the strength of the vertical exchange can be estimated. The result demonstrates the pattern that the vertical exchange time increases as the channel depth increases. In the downstream of the James River, the annual mean value of the vertical exchange time increases by about 4 days at a distance of $15 \mathrm{~km}$ from the river mouth where the mean channel depth changes from 9.38 to $12.31 \mathrm{~m}$ (Figure $5 \mathrm{~b}$ ). Because the vertical exchange time represents the water exchange between the surface and bottom, the exchange occurs vertically and the lateral transport 
can also increase the exchange. Therefore, the change is more evident. For the sea-level rise cases, the vertical exchange time decreases slightly. The age change caused by sea-level rise is less than that caused by channel deepening.

\section{Discussion}

Previous studies have indicated that channel deepening can cause DO decrease due to an increase in stratification and decreases in vertical mixing result in reducing DO aeration [7-9,51,52]. A recent study showed that a relatively small $(15 \%)$ increase in depth can double the exchange flow in an estuary [5]. An increase in exchange flow indicates an increase in gravitational circulation, which is favorable for DO, if DO is high at the outside of the estuary $[17,25]$. Sea-level rise impacts on hydrodynamics and DO are similar to channel deepening in a uniform channel. However, it can be very differently due to the depth increase in the entire estuary resulting in volume increase, especially for a relatively shallow estuary. Sea-level rise can increase stratification and decrease vertical mixing, but it can also increase gravitational circulation and residence time [18]. Recent studies of the Chesapeake Bay have shown that a sea-level rise of $0.5 \mathrm{~m}$ reduced summer hypoxia volume by $12 \%$ [11] and increased bottom DO [12]. This was mainly due to increased estuarine circulation that promoted oxygen-rich seawater intrusion in the lower layer [11]. For the James River, sea-level rise results in a slight decrease in summer DO, resulting from competition between changes in estuarine circulation and vertical mixing. An increase in water volume, saltwater age (Figure 5), and a decrease in vertical exchange time are the main causes of DO decrease. When water volume increases, residence time can increase [18], which could increase retention time of organic matters. It appears changes in DO due to channel deepening and sea-level can be diverse depending on the interaction of geometry, hydrodynamic condition, and DO condition at the open boundary.

The competition between a decrease in vertical exchange due to an increase in stratification and a DO increase due to an increase in gravitational circulation needs to be analyzed for different estuaries. The results may be difficult to compare for different scenarios and for different estuaries. To understand the impact of hydrodynamics on DO due to channel deepening and sea-level rise in a general sense, the impact of these two dynamic factors on DO was investigated by examining the corresponding transport times. According to Equation (3), the bottom DO can be determined by the timescales of vertical exchange process, gravitational circulation, and biochemical oxygen consumption. Because the change in DO is expressed by the timescales, the impact of hydrodynamics on DO can be measured by a common measure and is applicable to different scenarios. The non-dimensional parameters, $\tau_{b}^{*}$ and $\tau_{e}^{*}$, at Station LE5-4 are selected and computed from each scenario in summer. The constant DO consumption rate of 0.32 per day was used [32] for the summer period. The saturation DO is $7.5 \mathrm{mg}$ $\mathrm{O}_{2} / 1$ and $\tau_{b}$ is about 23.4 days. The results are plotted in Figure 6 . It can be seen that, for the channel deepening simulation, the vertical transport time increases as channel depth increases, resulting in a decrease in $\tau_{b}^{*}$ (reciprocal to $\tau_{v}$ with channel depth increase). In addition, the timescale measuring gravitational circulation decreases as the channel depth increases, resulting in a decrease in $\tau_{e}^{*}$ as well. As these two factors compensate each other, the change in DO follows the same normalized contour line, suggesting that the $\mathrm{DO}$ will not change much. The results agree with the $3 \mathrm{D}$ eutrophication model results (Table 3). It can be seen that the competition of these two dynamic processes modulates DO. For the sea-level rise scenario, the vertical transport time does not change much, but $\tau_{e}$ increases slightly. Therefore, the normalized DO deviates slightly from the baseline condition, indicating that DO will decrease slightly, but no significant change in DO is expected. For the James River, sea-level rise decreases summer DO slightly resulting from competition between an increase in estuarine circulation and a decrease in vertical mixing. 


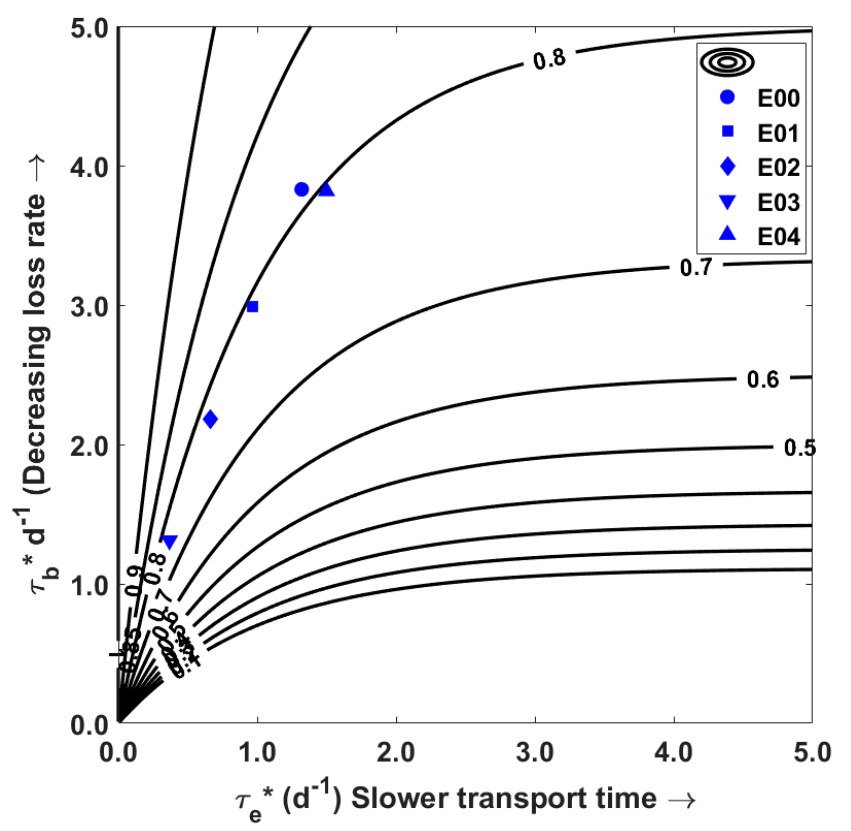

Figure 6. Normalized DO distribution under different conditions at Station LE5-4 (counters are O: Os, the ratio of the bottom-layer DO to surface-layer DO; circle represents E00; square represents E01; diamond represents E02; downward-pointing triangle represents E03; upward-pointing triangle represents E04).

For this study we focused on the impact of hydrodynamics on DO due to channel deepening and sea-level rise. Because a change of hydrodynamics can also affect nutrients and phytoplankton distributions, and nutrient deposition to the bottom sediment, it could also affect the biochemical process indirectly. For example, an increase in residence time due to sea-level rise can increase the volume of the estuary and affect nutrient retention time. According to current model experiments, the impact of hydrodynamics on DO is not large, but it can affect the nutrient distribution, which may affect phytoplankton. More studies are needed regarding the influences on biochemical processes, especially temperature effect considered to be due to climate changes.

\section{Conclusions}

A well-calibrated three-dimensional eutrophication model was used to conduct numerical experiments to study changes in hydrodynamics and DO in the James River under different scenarios of channel deepening and sea-level rise. Our results show that the channel deepening changes the horizontal salinity gradient, and also increases the tidal amplitude. The gravitational circulation strength and the vertical stratification both increase when the channel depth increases. However, the DO has experienced only a minor change. We found that the minor change could be explained by the competition of vertical and horizontal DO replenishments. These two processes compete against each other, and their combined effects result in a small DO change. To understand the competition, a new approach using timescales was applied to evaluate the impact of changes in hydrodynamic conditions on DO. The saltwater age that represents the timescale of gravitational circulation decreases when the channel depth increases, while the vertical exchange time increases after the channel deepening. The changes in these two key timescales effectively explain the minor change of DO. Sea-level rise increases both depth and volume of an estuary and alters the hydrodynamics and circulation of the estuary. The impact of a sea-level rise of $1.0 \mathrm{~m}$ on DO is larger than that of channel deepening, mainly due to slight decreases in gravitational circulation strength. The timescales of gravitational circulation and vertical exchange can be used to explain the impact of changes in hydrodynamics on DO. As timescales can be compared for different scenarios and different estuaries, it provides a common measure for understanding the impact of channel deepening and sea-level rise on DO in estuaries. 
Author Contributions: Both authors contributed to project design, model experiments, result analysis, and manuscript preparation. Y.W. conducted numerical model simulations. All authors have read and agreed to the published version of the manuscript.

Funding: This work is partially supported by DEQ under the project of the development of a water quality model to support the assessment of the Chl a standard, and the Virginia Port Authority for assessing the impact of channel deepening on DO through Moffatt and Nichol.

Acknowledgments: We thank reviewers' comments and suggestions, which improve the manuscript. We are grateful to Jiabi Du and Qubin Qin for their helpful comments. We thank Mac Sisson for his assisting in editing the manuscript. This work was performed using computational facilities at the College of William and Mary which were enabled by grants from Sun Microsystems, the National Science Foundation, and Virginia's Commonwealth Technology Research Fund. This is Contribution No. 3967 of the Virginia Institution of Marine Science, College of William and Mary.

Conflicts of Interest: The study is conducted at the Virginia Institute of Marine Science. The authors declare no conflict of interest.

\section{References}

1. Pritchard, D.W. Salinity distribution and circulation in the Chesapeake estuarine system. J. Mar. Res. 1952, 11, 106-123.

2. Pritchard, D.W. The dynamic structure of a coastal plain estuary. J. Mar. Res. 1956, 15, 33-42.

3. Familkhalili, R.; Talke, S.A. The effect of channel deepening on tides and storm surge: A case study of Wilmington, NC. Geophys. Res. Lett. 2016, 43, 9138-9147. [CrossRef]

4. Du, J.; Shen, J.; Zhang, Y.; Ye, F.; Liu, Z.; Wang, Z.; Wang, Y.P.; Yu, X.; Sisson, M.; Wang, H. Tidal response to sea-level rise in different types of estuaries: The importance of length, bathymetry, and geometry. Geophys. Res. Lett. 2018, 45. [CrossRef]

5. Chant, R.; Talke, S.A.; Sommerfield, C. Impact of Channel Deepening on Tidal and Gravitational Circulation in a2 Highly Engineered Estuarine Basin. Estuaries Coasts 2018, 41, 1587-1600. [CrossRef]

6. Hansen, D.V.; Rattray, M. Gravitational circulation in straits and estuaries. J. Mar. Res. 1965, 23, $104-122$.

7. Sangita, S.; Satapathy, D.R.; Kar, R.N.; Randa, C.R. Impact of dredging on coastal water quality of Dhammra, Orssa. Indian J. Geo Mar. Sci. 2014, 43, 33-38.

8. Brown, L.C.; Barnwell, T.O., Jr. The Enhanced Stream Water Quality Models, Qual-2E and Qual-2E UNCAS: Documentation and Users Manual; EPA/600/3-87/007; U.S. Environmental Protection Agency: Athens, GA, USA, 1987.

9. Kaur, J.; Jaligama, G.; Atkinson, J.F.; DePinto, J.V. Modeling dissolved oxygen in a dredged Lake Erie tributary. J. Great Lakes Res. 2007, 33, 62-82. [CrossRef]

10. Falkowski, P.G.; Hopkins, T.S.; Walsh, J.J. An analysis of factors affecting oxygen depletion in the New York Bight. J. Mar. Res. 1980, 38, 479-506.

11. Wang, P.; Linker, L.; Wang, H.; Bhatt, G.; Yactayo, G.; Hinson, K.; Tian, R. Assessing water quality of the Chesapeake Bay by the impact. In Proceedings of the IOP Conference Series: Earth and Environmental Science, 3rd International Conference on Water Resource and Environment (WRE 2017), Qingdao, China, 26-29 June 2017; IOP Publishing Ltd.: Bristol, UK, 2007; Volume 82. [CrossRef]

12. Irby, I.D.; Friedrichs, M.A.M.; Da, F.; Hinson, K.E. The competing impacts of climate change and nutrient reductions on dissolved oxygen in Chesapeake Bay. Biogeosciences 2018, 15, 2649-2668. [CrossRef]

13. Kemp, W.M.; Boynton, W.R.; Adolf, J.E.; Boesch, D.F.; Boicourt, W.C.; Brush, G.; Cornwell, J.C.; Fisher, T.R.; Glibert, P.M.; Hagy, J.D. Eutrophication of Chesapeake Bay: Historical trends and ecological interactions. Mar. Ecol. Prog. Ser. 2005, 303, 1-29. [CrossRef]

14. Cerco, C.; Noel, M. The 2002 Chesapeake Bay Eutrophication Model; EPA 903-R-04-004; US Army Engineer Research and Development Center: Vicksburg, MS, USA, 2004.

15. Officer, C.B.; Biggs, R.B.; Taft, J.L.; Cronin, L.E.; Tyler, M.A.; Boynton, W.R. Chesapeake Bay anoxia: Origin, development, and significance. Science 1984, 223. [CrossRef] [PubMed]

16. Kuo, A.Y.; Neilson, B.J. Hypoxia and salinity in Virginia estuaries. Estuaries 1987, 10, 277-283. [CrossRef]

17. Kuo, A.Y.; Park, K.; Moustafa, M.Z. Spatial and temporal variabilities of hypoxia in the Rappahannock River, Virginia. Estuaries 1991, 14, 113-121. [CrossRef] 
18. Hong, B.; Shen, J. Responses of estuarine salinity and transport processes to potential future sea-level rise in the Chesapeake Bay. Estuar. Coast. Shelf Sci. 2012, 104-105, 33-45. [CrossRef]

19. Wang, Y.; Shen, J.; He, Q. A numerical model study of the transport timescale and change of estuarine circulation due to waterway constructions in the Changjiang Estuary, China. J. Mar. Syst. 2010, 82, 154-170. [CrossRef]

20. de Jonge, V.N. Relation between annual dredging activities, suspended matter concentrations, and the development of the tidal regime in the Ems estuary. Can. J. Fish. Aquat. Sci. 1983, 40, 289-300. [CrossRef]

21. de Jonge, V.N.; Schuttelaars, H.M.; van Beusekom, J.E.E.; Talke, S.A.; de Swart, H.E. The influence of channel deepening on estuarine turbidity levels and dynamics, as exemplified by the Ems estuary. Estuar. Coast. Shelf Sci. 2014, 139, 46-59. [CrossRef]

22. U.S. Climate Change Science Program. Coastal Sensitivity to Sea-Level Rise: A Focus on the Mid-Atlantic Region. A Report by the U.S. Climate Change Science Program and the Subcommittee on Global Change Research; U.S. Environmental Protection Agency: Washington, DC, USA, 2009; 320p.

23. Kerner, M. Effects of deepening the Elbe Estuary on sediment regime and water quality. Estuar. Coast. Shelf Sci. 2007, 75, 492-500. [CrossRef]

24. Zhu, J.; Weisberg, R.H.; Zheng, L.; Han, S. Influences of channel deepening and widening on the tidal and nontidal circulations of Tampa Bay. Estuaries Coasts 2015, 38, 132-150. [CrossRef]

25. Shen, J.; Hong, B.; Kuo, A.Y. Using timescales to interpret dissolved oxygen distributions in the bottom waters of Chesapeake Bay. Limnol. Oceanogr. Methods 2013, 58, 2237-2248. [CrossRef]

26. Boynton, W.R.; Kemp, W.M. Nutrient regeneration and oxygen consumption by sediments along an estuarine salinity gradient. Mar. Ecol. Prog. Ser. 1985, 23, 45-55. [CrossRef]

27. Deleersnijder, E.; Campin, J.M.; Delhez, E.J.M. The concept of age in marine modelling: I. Theory and preliminary model results. J. Mar. Syst. 2001, 28, 229-267. [CrossRef]

28. Delhez, E.J.M.; Lacroix, G.; Deleersnijder, E. The age as a diagnostic of the dynamics of marine ecosystem models. Ocean Dyn. 2004, 54, 221-231. [CrossRef]

29. Malone, T.C. Effects of water column processes on dissolved oxygen, nutrients, phytoplankton and zooplankton. In Oxygen Dynamics in the Chesapeake Bay: A Synthesis of Recent Research; Smith, D.E., Leffler, M., Mackiernan, G., Eds.; Maryland Sea Grant College: College Park, MD, USA, 1992; pp. 61-112.

30. Nixon, S.W.; Ammerman, J.W.; Atkinson, L.P.; Berounsky, V.M.; Billen, G.; Boicourt, W.C.; Boynton, W.R.; Church, T.M.; Ditoro, D.M.; Elmgren, R. The fate of nitrogen and phosphorus at the land-sea margin of the North Atlantic Ocean. Biogeochemistry 1996, 35, 141-180. [CrossRef]

31. Lucas, L.V.; Thompson, J.K.; Brown, L.R. Why are diverse relationships observed between phytoplankton biomass and transport time? Limnol. Oceanogr. 2009, 54, 381-390. [CrossRef]

32. Du, J.; Shen, J. Decoupling the influence of biological and physical processes on the dissolved oxygen in the Chesapeake Bay. J. Geophys. Res. Ocean. 2015, 120, 78-93. [CrossRef]

33. Hong, B.; Shen, J. Linking dynamics of transport timescale and variations of hypoxia in the Chesapeake Bay. J. Geophys. Res. Ocean. 2013, 118, 6017-6029. [CrossRef]

34. Shen, J.; Wang, Y.; Sisson, M. Development of the hydrodynamic model for long-term simulation of water quality processes of the tidal James River. J. Mar. Sci. Eng. 2016, 4, 82. [CrossRef]

35. Hamrick, J.M. A Three-Dimensional Environmental Fluid Dynamics Computer Code: Theoretical and Computational Aspects; Special Report in Applied Marine Science and Ocean Engineering. No. 317; Virginia Institute of Marine Science, College of William and Mary: Williamsburg, VA, USA, 1992.

36. Hamrick, J.M.; Wu, T.S. Computational Design and Optimization of the EFDC/HEM3D Surface Water Hydrodynamic and Eutrophication Models; Society of Industrial and Applied Mathematics: Philadelphia, PA, USA, 1997; pp. 143-161.

37. Park, K.; Kuo, A.Y.; Shen, J.; Hamrick, J.M. A three-Dimensional Hydrodynamic-Eutrophication Model (HEM-3D): Description of Water Quality and Sediment Process Submodels; Virginia Institute of Marine Science: Gloucester Point, VA, USA, 1995.

38. Mellor, G.L.; Yamada, T. Development of a turbulence closure model for geophysical fluid problems. Rev. Geophys. Space Phys. 1982, 20, 851-875. [CrossRef]

39. Galperin, B.; Kantha, L.H.; Rosati, A.; Hassid, S. A quasi-equilibrium turbulent energy model for geophysical flows. J. Atmos. Sci. 1988, 45, 55-62. [CrossRef] 
40. Shen, J.; Qin, Q. James River Water Quality Model Refinement and Scenario Simulations; Special Reports in Applied Marine Science and Ocean Engineering (SRAMSOE) No. 474; Virginia Institute of Marine Science: Gloucester Point, VA, USA; College of William \& Mary: Williamsburg, VA, USA, 2020. [CrossRef]

41. Shen, J.; Haas, L. Calculating age and residence time in the tidal York River using three-dimensional model experiments. Estuar. Coast. Shelf Sci. 2004, 61, 449-461. [CrossRef]

42. Gustafsson, K.E.; Bendtsen, J. Elucidating the dynamics and mixing agents of a shallow fjord through age tracer modelling. Estuar. Coast. Shelf Sci. 2007, 74, 641-654. [CrossRef]

43. Rice, K.C.; Hong, B.; Shen, J. Assessment of salinity intrusion in the James and Chickahominy Rivers as a result of simulated sea-level rise in Chesapeake Bay, East Coast, USA. J. Environ. Manag. 2012, 111, 61-69. [CrossRef] [PubMed]

44. Titus, J.G.; Hudgens, D.E.; Trescott, D.L.; Craghan, M.; Nuckols, W.H.; Hershner, C.H.; Kassakian, J.M.; Linn, C.J.; Merritt, P.G.; McCue, T.M.; et al. State and local governments plan for development of most land vulnerable to rising sea level along the US Atlantic coast. Encviron. Res. Lett. 2009, 4, 4. [CrossRef]

45. Murphy, R.R.; Kemp, W.M.; Ball, W.P. Long-Term Trends in Chesapeake Bay Seasonal Hypoxia, Stratification, and Nutrient Loading. Estuaries Coasts 2011, 34, 1293-1309. [CrossRef]

46. Knauss, J.A. Introduction to Physical Oceanography, 2nd ed.; Prentice Hall: Upper Saddle River, NJ, USA, 1997.

47. Taylor, K.E. Summarizing multiple aspects of model performance in a single diagram. J. Geophys. Res. 2001, 106, 7183-7192. [CrossRef]

48. Friedrichs, C.T.; Aubrey, D.G. Tidal propagation in strongly convergent channels. J. Geophys. Res. 1994, 99, 3321-3336. [CrossRef]

49. Scully, M.E.; Geyer, W.R.; Lerczak, J.A. The Influence of Lateral Advection on the Residual Estuarine Circulation: A Numerical Modeling Study of the Hudson River Estuary. J. Phys. Oceanogr. 2009, 39, 107-124. [CrossRef]

50. Hong, B.; Liu, Z.; Shen, J.; Wu, H.; Gong, W.; Xu, H.; Wang, D. Potential physical impacts of sea-level rise on the Pearl River Estuary, China. J. Mar. Syst. 2019, 201, 103245. [CrossRef]

51. Bendtsen, J.; Gustafsson, K.E.; Söderkvist, J.; Hansen, J.L.S. Ventilation of bottom water in the North Sea-Baltic Sea transition zone. J. Mar. Syst. 2009, 75, 138-149. [CrossRef]

52. Boicourt, W.C. The influences of circulation processes on dissolved oxygen in Chesapeake Bay. In Dissolved Oxygen in Chesapeake Bay; Smith, D., Leffler, M., Mackiernan, G., Eds.; Maryland Sea Grant: College Park, MD, USA, 1992; pp. 7-59.

Publisher's Note: MDPI stays neutral with regard to jurisdictional claims in published maps and institutional affiliations.

(C) 2020 by the authors. Licensee MDPI, Basel, Switzerland. This article is an open access article distributed under the terms and conditions of the Creative Commons Attribution (CC BY) license (http://creativecommons.org/licenses/by/4.0/). 